23. До и после пострига: в 2 т. Киев: Типография Киево-Печерской лавры, 2016. Т. 1. $615 \mathrm{c}$.

24. Лавра. Четыре сезона. Киев: Свято-Успенская Киево-Печерская лавра, 2018. 513 с.

25. Аверинцев С. Поэтика ранневизантийской литературы. Москва: CODA, 1997. 343 с.

\title{
SUMMARY
}

\section{Spiritual downfall in ascetic thought of the Kiev-Pechersk Patericus}

George Pankov

Spiritual downfall is observed as an essential link in Christian ascetic practice. Three fragments of the Kiev-Pechersk Patericus are investigated in the article with three different situations of the spiritual downfall of the ascetics - through avarice, vanity and hatred for their neighbour. Their analysis permits us to define the hagiographic myth as a sociocultural channel for the presentation and transmission of the ascetic ideology of Orthodoxy with its regulatory mechanism. It is shown that the texts of the Kiev-Pechersk Patericus not only project the ascetic ideology prevailing in Christianity, but also form an ideological mechanism for regulating the spiritual practice of the ascetics. It is emphasized that the process of external regulation of the ascetic's life by the Christian tradition induces the Ascetics to work out a self-regulation mechanism, in which a spiritual decline / restoration takes on the significance of a significant motivational factor in expanding and deepening of the ascetic lifestyle.

Considerable attention is paid to understanding of the status of the inevitable death of the soul, which is constituted in a myth-poetic form as the most important motivational mechanism for activating self-motivated activity in the direction of the restoring of the spiritual state of the Ascetic. The role of the mythology of the Kiev-Pechersk Patericus is substantiated in the sense-life orientation, as well as in the personalization of the ascetic figure, which looks like a transcending person in the direction of the Christian ideal of holiness. The attention is paid to the fact that by the means of the value scale, the mythology of Kiev-Pechersk Patericus also realizes the function of the sense vital orientation and alongside with it the personalization of the image of the Ascetics which looks like a transcending personality towards the Alternative.

Keywords: spiritual decline, spiritual elevation, ascetic thought, hagiographic myth, being-insituation-threat, Alternative

\section{Тетяна Цимбал}

\section{Homo viator vs. "людина вкорінена" в католицькому екзистенціалізмі Габріеля Марселя}

Представлені результати соціально-філософського дослідження проблеми людини в католицькому екзистенціалізмі Габріеля Марселя. Підкреслюється, що на відміну від традиційної спрямованості релігійної філософії на покірний послух людини Богові, мислитель віддає перевагу особистому пошуку людини і створенню власного духовного світу. Обгрунтовано думку Г. Марселя про необхідність євангелізації душі як шляху подолання антропоцентризму і ствердження екзистенціалів свободи, братства, любові, надії, рівності, що є основою буттєвої вкоріненості людини. 3'ясовано, що сутність людини Г. Марсель вбачає в образі homo viator- особи вкоріненої не локально, а онтологічно, яка долає свій шлях до Бога, набуваючи трагічну мудрість.

Ключові слова: людина, homo viator, буттєве вкорінення, братерство, свобода 
В усі часи осмислення проблеми буття людини було ключовим завданням філософії й залишається пріоритетним шляхом до розуміння багатьох важливих аспектів сучасного глобалізованого світу. Ця проблема $є$ фокусом, у якому перетинаються магістральні лінії більшості філософських напрямків, своєрідною віссю, навколо якої обертаються різноманітні течії новітньої філософії. Крім того, проблема буття людини у своєму практичному вимірі постає перед кожною особою у важкі, кризові моменти життя, кількість яких невпинно збільшується з огляду на глобальні трансформації життя, наявність перманентних “граничних ситуацій”, плюралізацію стилістики соціокультурного простору. Актуальність дослідження проблеми життя людини в контексті реалій глобалізованого світу посилюється духовною інфляцією, ціннісною девальвацією та культурною інволюцією, що охоплюють усі суспільства. Реальне життя людини сучасної цивілізації помітно розходиться з цінностями гуманізму і засвідчує “буття-зкраїв”, існування людини “при-бутті”. Власне тому сучасна філософія повинна сфокусувати увагу на індивідуальному житті людини як реальному процесі та екзистенційній цінності.

У даному аспекті доречним є звернення до різних філософських течій, в тому числі, й до релігійної, і до антропоцентричної філософії. Підкреслимо, що у XX ст. відбулася переорієнтація більшості традиційної релігійної філософії від суворого дотримання принципу теоцентризму до філософсько-антропологічного спрямування близького екзистенціалізму та феноменології. Нові тенденції релігійно-персоналістичної філософії представлені іменами П. Тейяра де Шардена, Г. Марселя, Ж. Марітена та інших, котрі, у порівнянні із традиційним томізмом, значно лібералізували свої філософські погляди, залишаючи простір для самовизначення та саморозвитку особи, і водночас, підкреслюючи неможливість достеменного пізнання людини - найбільшої таїни світу.

Зауважимо, що в цілому ряді філософських концепцій стверджується положення про принципову непізнаваність людської індивідуальності. У християнському персоналізмі такий погляд $є$ наслідком індетермінізму стосовно свободи волі та автономності людини, але одночасно стверджується й залежність індивіда від світу вищого, божественного. В екзистенційній філософії непізнаваність пояснюється тим, що особистість визначається виключно суб'єктивними внутрішніми переживаннями, адже життя індивіда - це процес самопізнання закинутого у світ “Я”, яке неможливо осягнути зовні за допомогою емпіричних методів. Очевидно, що названі філософські напрями мають різні онтологічні платформи: християнський персоналізм грунтується на есенціалізмі, відповідно до якого індивід має визначене місце у створеній вищими силами ієрархії, має певні родові атрибути i складається з душі і тіла; екзистенціалізм виходить 3 того, що конкретний індивід не має певної визначеності, природної есенції, а його існування - первинне щодо сутності, яка створюється як результат вільних і відповідальних рішень. Проте в 
історії філософії є мислителі, котрі певним чином намагаються поєднати окреслені підходи. Це, перш за все, - С. К'єркегор, М. Шелер, Е. Муньє, Г. Марсель, К. Ясперс та інші. Серед них необхідно виділити християнський (або католицький) екзистенціалізм одного з найвідоміших філософів XX ст. Габрієля Марселя, котрий вибудовує свою концепцію життя людини як мандрівки, опираючись на складне онтологічне підгрунтя, що об'єднує уявлення про надприродний світ та філософію конкретного індивідуального буття, на філософський доробок католицького персоналізму та екзистенціалізму.

Метою даної статті є поглиблення розуміння проблеми життя людини у вченні Г. Марселя та виявлення у ньому точок дотику до авторської концепції буттєвого вкорінення особи.

Філософію Г. Марселя (зокрема у контексті співвідношення католицького персоналізму та екзистенціалізму) вивчали В. Візгін, Б. Губман, Д. Д’яков, А. Мартисевич, Д. Кір'янов, Г. Таврізян, П. Рікер та інші [1-6]. Дослідники наголошують на тому, що Г. Марсель $є$ тим винятковим мислителем, який “продовжив справжню французьку традицію філософської культури: філософію “від першої особи”, $з$ яскраво вираженим індивідуальним началом, що залучає читача-співрозмовника до драматичних перипетій рефлексії, пережитого духовного досвіду"; мислителем, якого "у сучасній ситуації турбує те, що сциєнтифікація філософії позбавила її споконвічно властивих їй рис турботи, мудрості, позбавила якості індивідуального розмірковування, 3 яким нерозривно пов'язана особиста відповідальність мислителя" [5, с. 269].

Наукова новизна запропонованого підходу полягає у тому, що проблема життєвого шляху людини у філософії Г. Марселя розглядається нами в контексті авторської концепції буттєвого вкорінення людини. Власне категорія “вкорінення” бачиться нами у локальному та глобальному (онтологічному) вимірі. Локальна вкоріненість людини - це їі вкоріненість у рідному грунті Батьківщини, перебування в рідній культурі, мові, традиціях. В більш широкому вимірі укорінення визначається нами як онтологічна та соціокультурна категорія та екзистенціал, а саме: укорінення $\epsilon$ розумінням внутрішнього, духовного стрижня “зовнішньоі” людини як смислоутворюючої константи буття та потреби особистісного самовизначення в умовах “буття3-краю”; укорінення - це основа відмежування істинного життя від виживання, імітації, профанації та конформістської формалізації життя, що визначається нами як знекорінення (позбуттєвість, “буття-з-країв” або одна з граней соціокультурного відчуження); укорінення - це духовно-практичний феномен, “буття-для-себе” і “культура себе”, максимальна повнота буття людини, актуалізація і реалізація всіх іiі сутнісних сил, можливостей, здібностей, смислів культури, цілей та цінностей, горизонт особистісного темпорального простору для вияву екзистенціалів духовності, творчості, свободи, суверенності й відповідальності [7, с. 12-13].

Г. Марсель (1889-1973рр.), видатний європейський філософ і літератор, навчався у Сорбонні, в Колеж де Франс, де відчув значний вплив А. Бергсона, але на 
відміну від його теорії роз'єднання інтелекту й інтуїції, захопився шеллінгівською ідеєю інтелектуальної інтуїції. Пізніше Г. Марсель розвиває персоналістичноекзистенційну філософію, віддаючи пріоритетне місце метафізиці вірності та співпричетності. Певний час Марсель працював викладачем у ліцеях, співпрацював $з$ літературними журналами, писав філософські есе, драми, щоденники, серед яких знаменитий “Метафізичний щоденник”, що беззаперечно сприяв розвитку екзистенційної філософії та персоналізму у Франції.

Вихований в атеїстичній родині, у сорокарічному віці Г. Марсель прийняв католицтво і розгорнув свої філософські пошуки у такому напрямку, який традиційно називають “католицький екзистенціалізм”. Проте мислитель певним чином дистанціювався від неотомізму та офіційної доктрини Католицької церкви, зосередившись на осмисленні ситуації людини у світі. Найвідоміші філософські твори Г. Марселя - “Буття та володіння”, "Ноmo viator. Пролегомени до метафізики надії”, “Люди проти людського”, “Людина, що стала проблемою”, “Філософські фрагменти” та інші - зробили його мислителем зі світовим ім'ям, володарем думок, якого запрошували з лекціями до найвпливовіших університетів світу [8-11]. Один з циклів лекцій, що був прочитаний Марселем у Гарварді, виданий як монографія “Екзистенційні основи людської гідності”. Необхідно зауважити, що праці Г. Марселя мають не тільки філософську цінність, а й художню, адже мислитель вважав, що філософія - це особлива культура, і виключно людина обдарована у мистецтві любові до мудрості, що відчуває його глибоко й тонко, може через внутрішній духовний досвід описати свої думки, донести їх до більш широкого кола зацікавлених осіб.

Філософія Г. Марселя грунтується на описах досвіду переживань людини, тобто традиційному методі екзистенційної філософії, однак і проблеми основ буття, питання про буття та відчуження від нього, також у центрі уваги філософа, що наближує його до онтології та персоналізму. Тим не менш, Г. Марсель не вважає, що питання про буття $€$ філософським. Це таємниця, яка ніколи не може бути розгаданою. Єдина можливість, яка дається людині, - долучитися до буття та, можливо, наповнити сенсом власне існування, екзистенцію. "Причетність до буття не $\epsilon$ чимось позалюдським, абстрактним. Навпаки, причетність до буття... реалізується як причетність до життя Іншого. Причетність до буття є причетність до Ти... що робить ізольованого індивідуума істотою, яка живе соціальним життям, і таким чином знімає відчуження. Соціальна вірність грунтується на любові, і вона $є$ прообразом відношення людини до Божественного Ти" [11, с. 31]. Буття у філософії Марселя - це основа таких феноменів, як любов, вірність, братерство, надія; це щось справжнє, правдиве. Антиподом же категорії “буття” як головної характеристики присутності людини у світі, що залежить від Бога, є “володіння" як категорія, що означає несправжність, породжену бажаннями та "волею до влади".

Увага Г. Марселя сфокусована не на бутті як такому, а на “онтологічній таїні” існування особи, пошуку сталості, стабільності (або вкоріненості - Т. Ц.), реалізації 
сподівань людини, ствердження індивідуальної цінності в тому, що не піддається раціональному категоріальному визначенню, а сприймається як “почуття буття”. Сьогодні онтологічна потреба "бути” згасає в людині відповідно нівелюванню їі особистості. Однак ця потреба все ж зберігається у відчутті певних “розмитих” прагнень, адже поза буттям особистість стає “нічим”. Тому “зустріч з буттям”, яка й не завжди надійна, а іноді переходить у відчай, що не може бути основою буттєвого самоствердження людини, Г. Марсель все ж трактує як вихідну онтологічну обставину існування людини [10]. Буття, акцентує філософ, є актом відкритості, комунікації, залучення, тобто, є умовою вкоріненості індивідуального людського існування, а значить - основою любові, братерства, вірності.

Увага Марселя до індивіда, особистості, на противагу світу об'єктивності, приводить його до екзистенційної проблематики раніше, ніж у Свропі був остаточно оформлений власне екзистенціалізм. Об'єктивний світ, який за Марселем, представлений наукою і технікою, механізацією думки і політикою, господарством та виробництвом, втратив свою сутність через хижацькі прагнення людини. Саме люди перетворюють суспільство на суб’єкт, однак “...на які б технічні вдосконалення не було здібним суспільство, вона завжди буде лише квазіособистістю, псевдосуб'єктом" [8, с. 406]. Власне тому у центрі всіх філософських систем, вчень, розмислів повинна бути виключно конкретна людина як суб'єкт дії та пізнання, або екзистенціальний світ людини. Таке твердження дозволило Г. Марселю називати свою філософію “конкретною”, а їі завданням - осмислення людського буття.

Вирішення останньої приводить мислителя до однієї з провідних ідей необхідності “тотальної євангелізації душі” в умовах сучасної моральної кризи. Однак на відміну від традиційної орієнтації релігійної філософії на покору та слухняність людини перед Богом, Марсель, переформулювавши картезіанську тезу на "Я відчуваю, значить я існую", надає перевагу пошукам людиною свого “ Я”, самотворенню власного духовного світу, розвитку почуттів, емоцій, інтуїції. Найвищим же почуттям людини є почуття любові. Любити людину, за Марселем, означає чекати від неї чогось такого, що не піддається визначенню: “Чекати - це у певному сенсі давати; проте вірно й зворотне: припинити чекати - означає сприяння приреченості на безплідність істоти, від якої вже нічого не чекають, тобто... позбавити їі можливості проявити себе надзвичайним чином, творити” [11, с. 59]. В любові розкривається інтерсуб' єктивність особи, в ній - основа людського буття, відкритість, прихильність, що розповсюджується на всі сфери буття.

Найкращим же образом для розкриття сутності людини стає для Марселя homo viator - вічний мандрівник. Така людина - $з$ драматичною долею, страхами, відчуженням, відчаєм - вкорінюється онтологічно у процесі долання свого шляху до Бога, набуття трагічної мудрості. Зауважимо, що ця нова мудрість породжена трагедіями сучасності, і повинна, на думку Марселя, включити в себе все найцінніше й найгуманніше з мудрості минулого, із загальнолюдських норм та прин- 
ципів. Ідеалами буття людини, за Марселем, є екзистенціали свободи, братерства, любові, надії, рівності (дотичні до екзистенціалів авторської концепції буттєвого вкорінення людини), які не можуть бути об'єктивованими у предметній формі, однак безумовно даються людині у духовному досвіді.

Останнє твердження природне для Г. Марселя - людини глибоко віруючої. Проте, будучи католиком, він все ж не став фанатиком і приймав будь-які релігійні, духовні та інтелектуальні пошуки як філософські шукання. Відповідно, в його філософії міститься критика різних форм конформізму, сумніви у можливості застосування наукових методів до індивідуального буття людини, що у свою чергу служить ідеї відновлення зв'язку з “вищою дійсністю” та потребі знайдення дороговказу для сучасної людини на ризики та сподівання пошуків смислу життя шляхом “відкритості” іiї трансцендентному, позачасовому. Таким чином, відмова від світу випадковостей обов' язково приводить до визнання потойбічного світу. Людина, що загубилася у світі речей, у сповненому драм та трагедій світі соціальності, не почувається цілісною. Ї̈̈ роздвоєність призводить до пошуку вищих сил, божественного начала. Відкриття останнього дозволяє людині знайти онтологічну основу і втрачений сенс існування у світі. Однак в даному випадку відмежування екзистенції від соціальних зв'язків, досягнення автономності, незалежності від колективного життя, призводить до появи нових зв'язків і цінностей - релігійних. Вільна людина, самість, що зреклася світу, “рабства речей”, чекає, за Г. Марселем, “у тривозі голосу божого”, справжньої свободи.

Людина, закинута у світ, не може знайти життєві орієнтири на землі, але “може прочитати їх на небі”, приймаючи на себе “ризик віри”. Останній як ризик вільного вибору звільняє людину з полону “ніщо”, адже відкриття божественного дозволяє людині знайти втрачений сенс існування, онтологічні основи життя й життєвих виборів. Як зауважує К. Ясперс: “Бог є тією передумовою, завдяки якій після усіх сумнівів я знаходжу основу для своїх виборів у повсякденному житті” [12, с. 126]. Однак знаходження божественного начала не є кінцевою точкою шляху, а сам шлях є смислом дій індивіда, сенсом його екзистування, адже “бути означає бути в дорозі”, бути “homo viator”. Люди - лише мандрівники на Землі, а сенс нашого життя, на думку Марселя, - прагнення до Бога. Відкриваючи суть у мандруванні, прагненні до вищого, людина пізнає глибину та долає абсурдність життя.

Така позиція Г. Марселя викликала негативну реакцію атеїстичних філософів. Критикуючи християнський екзистенціалізм, Ж.-П. Сартр вважав головною помилкою Г. Марселя те, що він нібито намагався зробити людину всього лише слугою, рабом Божим [13]. У свою чергу, Марсель закидає Сартру зменшення значення свободи людини через надмірні пропозиції. Адже піднімаючи свободу людини на найвищий п'єдестал, Сартр бачить повне виявлення цієї свободи в кожному акті нашого існування, а у результаті принижує свободу. Для нього вільна людина - та, що не має коріння свого буття i не прагне його віднайти. До речі, Г. Марсель не називав свою філософію 
“християнський (або католицький) екзистенціалізм” саме через те, що не хотів здаватися послідовником Сартра.

Дійсно, за Сартром, людина сама прагне стати богом, i, відкидаючи ідею бога, людина стає вільною, яким є бог в уявленні віруючих. Будучи вільною як бог, людина може все. Однак по суті людина не є всесильною і досконалою як бог, вона не може робити все, i iї існування можливе тільки у соціумі. Таким чином, свобода можлива лише пропорційно самовдосконаленню і гуманізації міжособистісних стосунків, а також пристосування самої людини до відповідального використання цієї свободи. Істинна свобода повинна грунтуватися на справжній спільності, на збагаченні особистості індивіда, його моральній культурі та почутті громадянського обов'язку. Свобода ж не є даним від народження атрибутом людини, як вважав, наприклад, Ж.-Ж. Руссо, іiї необхідно виборювати причому, на думку Марселя, виключно у спільності з іншими, у відчутті братерства: “Максимально вільна людина... є людина, що найбільшою мірою наповнена духом братерства" [1].

Останній звільняє, дарує творчу свободу у відкритому діалозі, що беззаперечно приводить до духовного зростання братів. Причому це не абстрактне поняття, відсторонене від конкретної особи, індивідуальності, і не утилітарна комунікація, а життя у єднанні з доброї волі, синергія зростання, позитивний зв'язок людей. Саме у братерстві проявляється особистість і той рівень їі життя, який Марсель називає “у себе буттям” (тобто, вкоріненим буттям). Безпосередньо з братерством пов' язане і розуміння Марселем взаємовідносин екзистенції з буттям, що здійснюється через інших людей, через “ти”, у почутті любові як вищої і чистої форми інтерсуб'єктивності.

Відкриваючи іншому шлях до себе, людина одночасно стає відкритою і для самої себе. У розумінні необхідності відкритості та взаємності, Г. Марсель близький до діалогічної філософії М. Бубера та К. Ясперса, проте він вважає, що мої близькі не тільки відображені в мені, а є частиною мене, діалог - це й досвід спілкування з іншим собою.

Примітно у цьому контексті й те, що мірою справжнього покликання філософа-екзистенціаліста й митця, за Марселем, є “братське розуміння" усього живого. Останнє положення, на нашу думку, дуже близьке до концепції “благоговіння перед життям” А. Швейцера, однак для Марселя першочергове значення все ж має братерство між людьми як трансцендентна спорідненість. Братерство не було для філософа виключно теоретичним конструктом, він відчував близькість до православних християн, до тих, кого переслідувала влада. Наприклад, Солженіцина він вважав “своїм братом”. До таких думок Г. Марселя приводить болюче відчуття несвободи або загрози свободі та солідарність 3 тими, кого позбавляють свободи.

Не дивлячись на те, що в центрі філософії Г. Марселя людина, екзистенція, він критикує так званий практичний антропоцентризм, що нібито міг швидко 
вирішити усі існуючі проблеми. Самовпевненість такої позиції філософ відкидає і пояснює, що справжня мудрість сьогодні - це відмова від Его, від зосередженості на "Я”, це пошук причетності до буття (вкоріненості - Т. Ц.), а значить причетності до Бога, природи, універсуму. Марсель впевнений, що філософське осягнення світу й людини можливе виключно за умови наявності душевного досвіду, який час від часу переживає кожний. Цей досвід дозволяє людині подивитися на світ іншими очима. Наприклад, таїна народження дитини, смерть або любов $є$ потрясіннями, що преображають світ і стимулюють людину до пізнання, стають джерелом філософування. Навпаки ж, науково-технічний прогрес та функціональний підхід до світу призводять до вичерпання смислових ресурсів пошуку, до суму та нудьги.

Серед багатьох видів душевного досвіду, що піддавалися філософській рефлексії Марселя, необхідно виділити проблему евтаназії, як свободи розпоряджатися своїм тілом. Природно, що прихильники ії легалізації, виходять із поваги до людини, почуття гідності та права на автономні рішення. Однак і Г. Марсель, відкидаючи евтаназію, звертається до феномену людської гідності. Екзистенціальними основами гідності людини $\epsilon$, на його думку, не відносини володарювання та право розпоряджатися своїм тілом і життям, а сакральність життя людини, що має інтерсуб'єктивний характер. Тобто, якщо виходити із духовної сутності людини, ми не можемо знати, де закінчуємося ми і починається інша людина, у внутрішньому просторі ми перетікаємо одна в одну. Причому внутрішній простір, а значить інтерсуб'єктивність, $є$ більш реальними, ніж тіло. Крім того, Марсель виділяє “тіло-об'єкт” (чисто фізичне) і “тіло-суб” єкт” (просякнуте духовністю, а значить - сакральне). Власне сакральність як “над-предметне” буття і не дає філософу прийняти ідею евтаназії, висунуту прихильниками технократичного мислення. Як бачимо, проблему тілесності Г. Марсель розглядає у контексті “володіння”, вважаючи, що головна онтологічна проблема людини полягає у намаганні ототожнити речі, які принципово не можна ототожнювати ні з чим, тобто себе самого $з$ чимось конкретним: “Перший об’єкт... з яким я себе ідентифікую і який від мене вислизає, - це моє тіло”. За М. Фуко, тілесність $є$ первинним і універсальним досвідом буття, саме тіло дає відчуття неможливості існування людини поза світом речей, адже “спосіб буття... даний мені перш за все моїм тілом” [14, с. 405]. Однак тілесність $є$ образом неможливості володіння буттям, неможливості присвоєння буття і голосом буття одночасно. Саме завдяки першопочатковості тілесності як досвіду буття, поєднання внутрішнього й зовнішнього, ми отримуємо несвідому настанову на предметність. Проте існування людини, за Г. Марселем, “не може бути рівним предмету, про який ми могли б сказати, що він $є$ тут, тобто що він даний, що він знаходиться перед нами" [11, с. 28]. Людське існування може бути вловлено лише нами самими як тотожне нашому життю. Крім того, в контексті осмислення проблеми евтаназії, необхідно наголосити, що тільки Г. Марсель 3 усіх екзистенціалістів наголошує не на проблемі власної смерті, не на трагізмі 
усвідомлення завершення свого життя, а на трагедії від смерті ближнього. Таким чином, “буття-до-смерті” М. Хайдеггера як категорія, що віддзеркалює розуміння людиною власного виходу за межі земного життя, не має значення та смислу для Марселя. Навпаки, дійсно екзистенційним і трагічним є усвідомлення проблеми життя і смерті стосовно іншої, близької, рідної людини.

Отже, стислий огляд проведеного дослідження підтверджує наше припущення щодо дотичності авторської концепції буттєвого вкорінення людини до філософії Г. Марселя, що корелює з нею систему таких екзистенціалів, як свобода, любов, братерство, творчість, а також розумінням онтологічного рівня вкоріненості як перманентного поставання, самотворення та самоздійснення з образом homo viator як "вічного мандрівника".

Звичайно, в епоху сцієнтизму, пануючого в суспільстві технократизму, філософія Г. Марселя не може бути широко популярною. Але евристичний потенціал вчення філософа, глибину його персоналістичної та екзистенційної думки важко переоцінити, адже Марсель демонструє філософію, яка несе на собі відбиток двох світових воєн, трагічних подій XX ст. і говорить звичною людською мовою, філософію діалогу як практику повсякденного буття, філософію як духовний пошук і спосіб життя, тобто сократівську філософію, що не може залишати байдужими інших.

1. Визгин В. П. На пути к другому: от школы подозрения к философии доверия. Москва: Языки славянской культуры, 2004. 800 с.

2. Губман Б. Л. Марсель Габриэль // Современная западная философия: словарь. Москва: ТОН - Остожье, 2000. С. 246-247.

3. Дьяков Д., Мартысевич А. Проблема взаимодействия католической теологии начала середины XX века и философии экзистенциализма на примере неотомизма // Католицизм: традиція і сучасність: матеріали VIII міжнар. молодіжної релігієзнавчої літньої школи. Київ, 2010. C. $193-202$.

4. Кирьянов Д. В. Томистская философия ХХ века. Санкт-Петербург: Алетейя, 2009. 168 с. (Серия “Богословская и церковно-историческая библиотека").

5. Тавризян Г. М. Габриэль Марсель // Путь в философию: антология. Москва: ПЕР СЭ; Санкт-Петербург: Университетская книга, 2001. С. 268-272.

6. Поль Рикёр - Габриэль Марсель: беседы // Марсель Г. Трагическая мудрость философии: избр. работы. Москва: Издательство гуманитарной литературы, 1995. С. 146-187.

7. Цимбал Т. Буттєвісне укорінення людини. Київ: НПУ імені М. П. Драгоманова, 2005. $219 \mathrm{c}$.

8. Марсель Г. К трагической мудрости и за ее пределы // Проблема человека в западной философии. Москва: Прогресс, 1988. 552 с.

9. Марсель Г. Присутствие и бессмертие: избр. работы. Москва: Институт философии, теологии и истории св. Фомы, 2007. 328 с.

10. Марсель Г. Трагическая мудрость философии: избр. работы. Москва: Издательство гуманитарной литературы, $1995.216 \mathrm{c}$.

11. Марсель Г. Ното viator. Київ: Видавничий дім “КМ Academia”, Університетське видавництво “Пульсари”, 1999. 320 с. 
12. Ясперс К. Введение в философию. Минск: Пропилеи, 2000. 192 с.

13. Сартр Ж.-П. Экзистенциализм - это гуманізм // Сумерки богов. Москва: Политиздат, 1989. C. 319-344.

14. Фуко М. Слова и вещи. Археология гуманитарных наук. Москва: Прогресс, 1977. $488 \mathrm{c}$.

\section{SUMMARY}

\section{Homo viator vs. rooted human in the catholic existentialism of Gabriel Marcel}

The results of socio-philosophical study of human problem in the catholic existentialism of Gabriel Marcel are presented. It is emphasized that in contrast to the traditional orientation of religious philosophy on humble obedience of man to God, the thinker prefers the personal search of man and the creation of own spiritual world. At the same time, being aware of the existing moral crisis, Marcel justifies the need for the evangelization of the soul as a way of overcoming anthropocentrism and the assertion of the existentialists of freedom, brotherhood, love, hope, equality, which is the basis of human existential rootedness. Faith as the risk of free choice frees a man from captivity of "nothing", allowing a person to find the lost meaning of existence in the world, ontological foundations of life. The content of the categories "freedom" and "brotherhood" is analyzed and it is proved that true freedom is not a birth attribute of a person, but fights in common with others in the sense of brotherhood. It is emphasized that freedom is possible only in proportion to self-improvement, humanization of interpersonal relations. In turn, brotherhood frees people, gives creative freedom, unity with goodwill and synergy of spiritual growth. It is found that the best way of human G. Marcel considers homo viator - the eternal traveler, the person who is rooted not locally, but globally, ontologically. Such a person makes his way to God, knows the depth of life and overcomes the absurdity of life, gaining tragic wisdom. Thus, the teachings of G. Marcel represent a reflection of his ethical ideals, moral values and feelings, which opens up new possibilities for the assertion of philosophy as a spiritual search and a special way of life in modern conditions.

Keywords: human, homo viator, existential rooting, brotherhood, freedom 